\title{
Rzeszów as an example of a 'new town' tailored for the modern era
}

\author{
Anna Sikora \\ sikora@prz.edu.pl | @ https://orcid.org/0000-0002-3646-6924 \\ The Faculty of Civil and Environmental Engineering and Architecture, Rzeszow \\ University of Technology
}

Scientific Editor: Mateusz Gyurkovich, Cracow University of Technology Technical Editor: Matgorzata Sikora, Cracow University of Technology Press Language Editor: Tim Churcher, Big Picture Typesetting: Małgorzata Murat-Drożyńska, Cracow University of Technology Press

Received: July 30, 2020

Accepted: April 16, 2021

Copyright: ( 2021 Sikora. This is an open access article distributed under the terms of the Creative Commons Attribution License, which permits unrestricted use, distribution, and reproduction in any medium, provided the original author and source are credited.

Data Availability Statement: All relevant data are within the paper and its Supporting Information files.

Competing interests: The authors have declared that no competing interests exist.

Citation: Sikora, A. (2021). Rzeszów as an example of a 'new town' tailored for the modern era. Technical Transactions, e2021006. https://doi.org/ 10.37705/TechTrans/e2021006

\begin{abstract}
The city life cycle is an issue that can be considered from many perspectives. Klaassen's period cycle is the basic model of city life: urbanisationsuburbanisation-deurbanisation-reurbanisation. In each of these periods, cities develop by, building and transforming their structures. This article presents various approaches to shaping new urban spaces using the city of Rzeszów as an example. In the city's history, three periods are distinguished during which structures referred to as the 'new town' were created in the $16^{\text {th }}$ and $20^{\text {th }}$ centuries and continue to be created now. After analysing the site-forming processes, the most important features of new-town urban systems are compared.
\end{abstract}

Keywords: Rzeszów, new town, new territories, suburbanisation 


\section{Introduction}

Urban development is a complex issue. Assuming that the basic city life cycle is the model urbanisation-suburbanisation-deurbanisation-reurbanisation (Klaassen, 1981), and that the method of building urban tissue changes in terms of threshold (Malisz, 1981), the proper development of urban tissue is influenced by numerous factors changing over time depending upon the degree of technical development. Regardless of the development phase, one can risk the statement that in each identified period, 'new' territories are created, which are distinguished by the nature of their functional and spatial structure. Rzeszów is a city classified in the twentieth century to the group of quickly developing cities with high growth dynamics. These dynamics are influenced by spatial policy, which can be called growth through incorporation (Henning, 2012). The term 'new town' means two things to the inhabitants of Rzeszów, firstly as a historical reference to buildings and a new market built in the $16^{\text {th }}$ century in the vicinity of the old market (currently called the Freedom Square and referred to in the text new town XVI) and as the name of a large housing estate 'New Town' built on the canvas of the ten-story high-rise buildings in the 1980s (referred to in the text New town $X X$ ). For the purposes of the article, the areas connected to Rzeszów in 2006-2020 (referred to in the text New town XXI) were also named whatever you mean, referring to the names introduced when expanding the territory of Zielona Góra (Andrzejewska, 2018). Because the contamination of phrase 'new town' also repeatedly appears in the article, in order to organise the content, it is assumed that 'new town' is a general term for new urban tissue.

\section{Purpose and method}

The purpose of the study is to identify and describe the development processes of Rzeszów in relation to areas referred to as 'new town' in different periods of territorial growth. This issue is important in relation to the city selected for analysis due to its history and characteristic way of growth through a rapid increase in area. The working method is a comparative analysis of the processes and factors related to creating 'new cities' depending on the historical. The working method is a comparative analysis of the processes and factors creating 'new cities' depending on the historical period of activities and the development policy. An important element of the work is a tabular summary of the morphology of areas and the conclusions that contribute to expanded research on contemporary processes of building the structure of new urban territories.

\section{New town XVI as a competitive spatial arrangement centred around the square}

Rzeszów developed as a small trade settlement at the intersection of important trade routes: from Silesia to Red Ruthenia and further on to the Black Sea. The location of the city was made in 1354 , but it was secondary in nature - the first location, about which there is not much information, was made before 1340 (Pęckowski, 1913). The city's buildings were concentrated in the frontages of the medieval market, where the town hall was also located. The church located west of the urban fabric was the second public facility.

One of the most important phenomena for the development of Rzeszów was the settlement of the Jewish community in the city. The first mention of their stay dates back to 1550. Jews dealt mainly with trade, craft, running distilleries and financial trading, which caused competition and sometimes resentment from the inhabitants of other ethnic origins. An element of the regulation of Jewish presence in the city was a decree issued in 1595, which allowed all Jews to own only seven properties in the city. This limitation caused the construction of 
a Jewish district northeast of the city, where wooden houses were built around the Old Town Synagogue and the Jewish cemetery (Gosztyta, 2017).

The idea of creating the spatial layout of New Town XVI is probably associated with the Old Town fire of 1576 and the desire to implement Renaissance proportions in the structure of the growing settlement unit (Henning, 2012; Kiryk, 1994). However, it should be emphasised that there is disagreement among researchers regarding the location of the New Town. According to Henning, construction began at the end of the $16^{\text {th }}$ century (Gosztyta, 2017; Henning, 2012), while Kotula places this investment a hundred years later at the end of the $17^{\text {th }}$ century (Kotula, 1985). The fact that the buildings could only be located on hills, because they were surrounded by swamps and standing water, was significant for shaping the new housing estate. The central point of the district was the rectangular square measuring around $120 \times 125 \mathrm{~m}^{2}$ in the centre of which the scales and commercial stalls were placed. The shape of the square refers to the Renaissance cross system and is extremely similar to the first Renaissance market in Poland, located in the neighbouring city of Gtowów (now referred to as Gtogów Matopolski). The buildings accompanying the commercial public space is, according to Wiedemann's plan from 1762, mostly arcaded houses located on streets or squares. The whole complex was surrounded by modest fortifications - an earth embankment and a moat and, like the Old Town, by wetlands. New Town Miasto XVI was connected with the Old Town through a causeway built on the moat located on the southern side.

As in the Middle Ages, subsequent owners of Rzeszów refused to allow Jews to settle within the Old Town. This resulted in a high density of buildings in the Jewish quarter, which in time began to enter the area of the New Town XVI (Gosztyta, 2017). The New Town Synagogue was then built. Restrictions on the construction of Jewish houses ceased to be observed in the second half of the $17^{\text {th }}$ century, when refugees from Ukraine began to arrive in Rzeszów in large numbers, where numerous pogroms were taking place at that time. As early as 1674, the number of townspeople of Jewish origin was greater than that of other nationalities. In the $18^{\text {th }}$ century, Jews practically monopolised trade and craft (Pęckowski, 1913). Until the mid-19 ${ }^{\text {th }}$ century, marshes and wetlands were drained, then the buildings began to be more dispersed, so that the bipolar urban system began to get lost and the areas of the Old and New Towns XVI began to merge and become more integrated.

In the years of partitions and Galician autonomy, Rzeszów acquired a new function - it became the seat of local authorities in the structures of the tsarist administration. The so-called Tsar's Road became one of the leading investments

Fig. 1. Fragment of Wiedemann's Plan from 1762 (source: collection of the District Museum in Rzeszów)

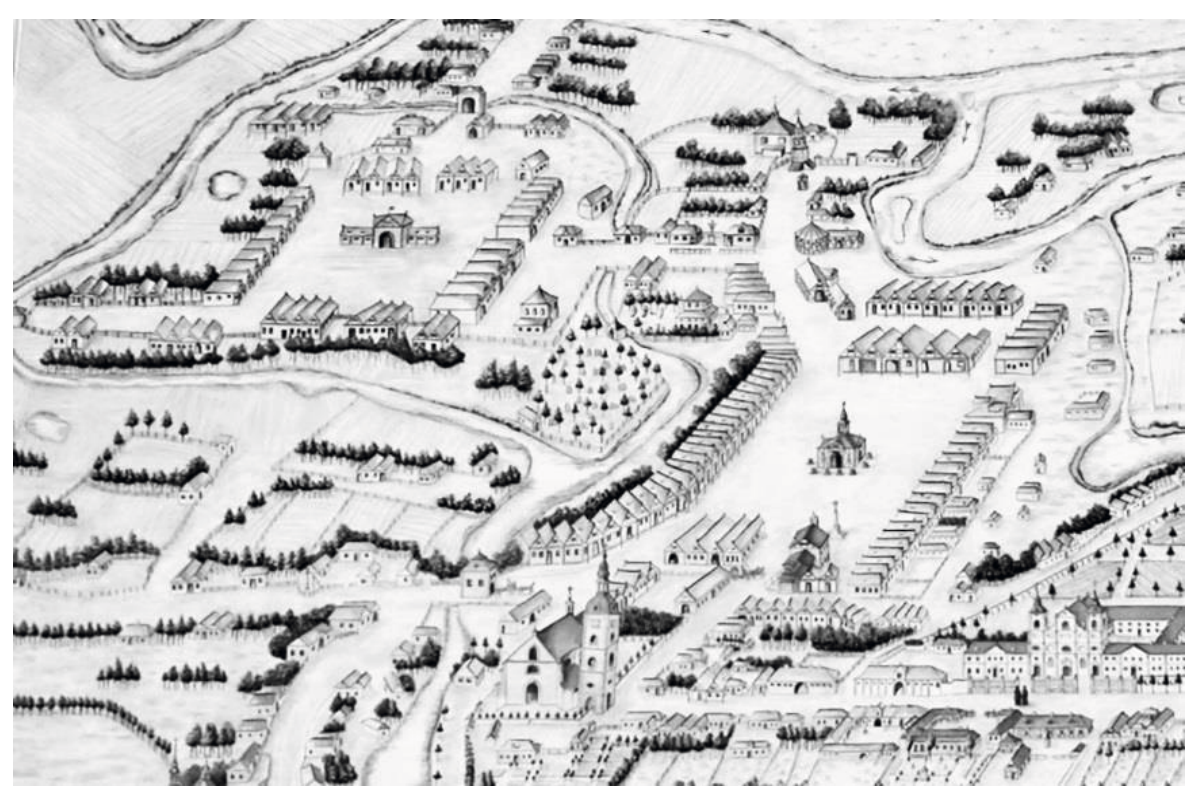


- a paved road on a strategic route from Bielsko, through Kraków, Tarnów, Rzeszów, Przemyśl to Lviv. It ran through the area of the New Town XVI - first across the bridge on the Wistok and then diagonally from the New Town Square from the east to the south. In the mid-19 $9^{\text {th }}$ century, a huge fire completely destroyed the buildings, but the construction of the Kraków-Rzeszów-Lviv railway line, and the barracks for the National Defence infantry in the vicinity of the New Town Square caused an increase in construction traffic and trade (Kiryk, 1998).

Until World War II, the New Town district was a Jewish district. In 19411944, a ghetto was created in the eastern part of the district, in which 12,000 Rzeszów Jews were gathered, together with the same number of Jews from nearby villages and towns. Most of them were murdered. Along with people, they also tried to destroy the memory of them by demolishing the cemetery and turning synagogues into warehouses. In 1944, both synagogues were burnt. After World War II, the focus was on building new settlements on the outskirts of the city, while rebuilding and renovating some objects. The synagogues were rebuilt according to new projects and given new functions (State Archives and Art Exhibition Bureau) and the site of the cemetery was turned into a park (Victims of the Ghetto). The final devastation of the urban structure of the area took place in the mid 1960s, when the majority of the New Town Market was turned into a wide road (Lenin Avenue, now Pitsudski Street), which was a communication grid of the socialist city under construction. The road was led across the diagonal line of the market, completely losing the old urban layout and turning the park into squares and interchange places for residents. Only the name - Freedom Square - serves as a reminder of the existence of the square (Wzorek, 1953).

\section{Housing estate from 'New Town' - New Town XX}

According to the idea of a modernist city, the segregation of functions that separated wide communication arteries was meant to be characteristic feature. The urban complex of the Old Town and New Town XVI entered the area of the delimited city centre (Sikora, 2008), which surrounded the structural neighbour units, namely housing estates. One of these was the New Town XX housing estate built on the eastern bank of the Wistok river. The estate was designed in accordance with the principles described in the Athens Charter (Le Corbusier, 2017), where high-rise residential buildings were located at relatively large distances from each other so as to ensure adequate lighting and ventilation of the apartments. Extensive green areas, despite them lacking a specific function, were to become recreational and leisure areas.

Areas on the eastern bank of the Wistok was a completely new area of high intensity development areas. The city's development in this area was anticipated in the interwar period and post-war development plans detailed these concepts (Moskal, 2015). In 1959, a nationwide SARP competition for the housing estate project was announced. Twenty-nine teams from all over Poland took part in the competition, and the first prize went to a team of architects from Katowice (R. Ćwikliński, Z. Fagas, M. Król) (Henning, 2012). Unfortunately, due to the lack of funds in the city budget, the investment was abandoned. The program arrangements made by the designers of the winning work were later used in the prospective general development plan for Rzeszów developed in 1968 and the detailed spatial development plan for the New Town district. The plans were developed by the City's Urban Workshop under the direction of $\mathrm{W}$. Henning and J. Lisowski. The planning documents became the basis for defining the guidelines in the simplified urban-architectural competition, to which four design offices were invited (one each from Katowice and Warsaw, and two from Rzeszów). The concept of the Warsaw office was selected from the Inwestprojekt-Michalin office (W. Rzepka, Z. Pawelski, A. Dzierżawski). This project was distinguished by the simplicity and repeatability of the urban layout, which resulted in a significant reduction in investment costs. At the same time, 
Fig. 2. Design of the New City Miasto XX district - the first-prize winner in the competition, prepared by the Inwestprojekt Michalin studio (Henning, 2012)

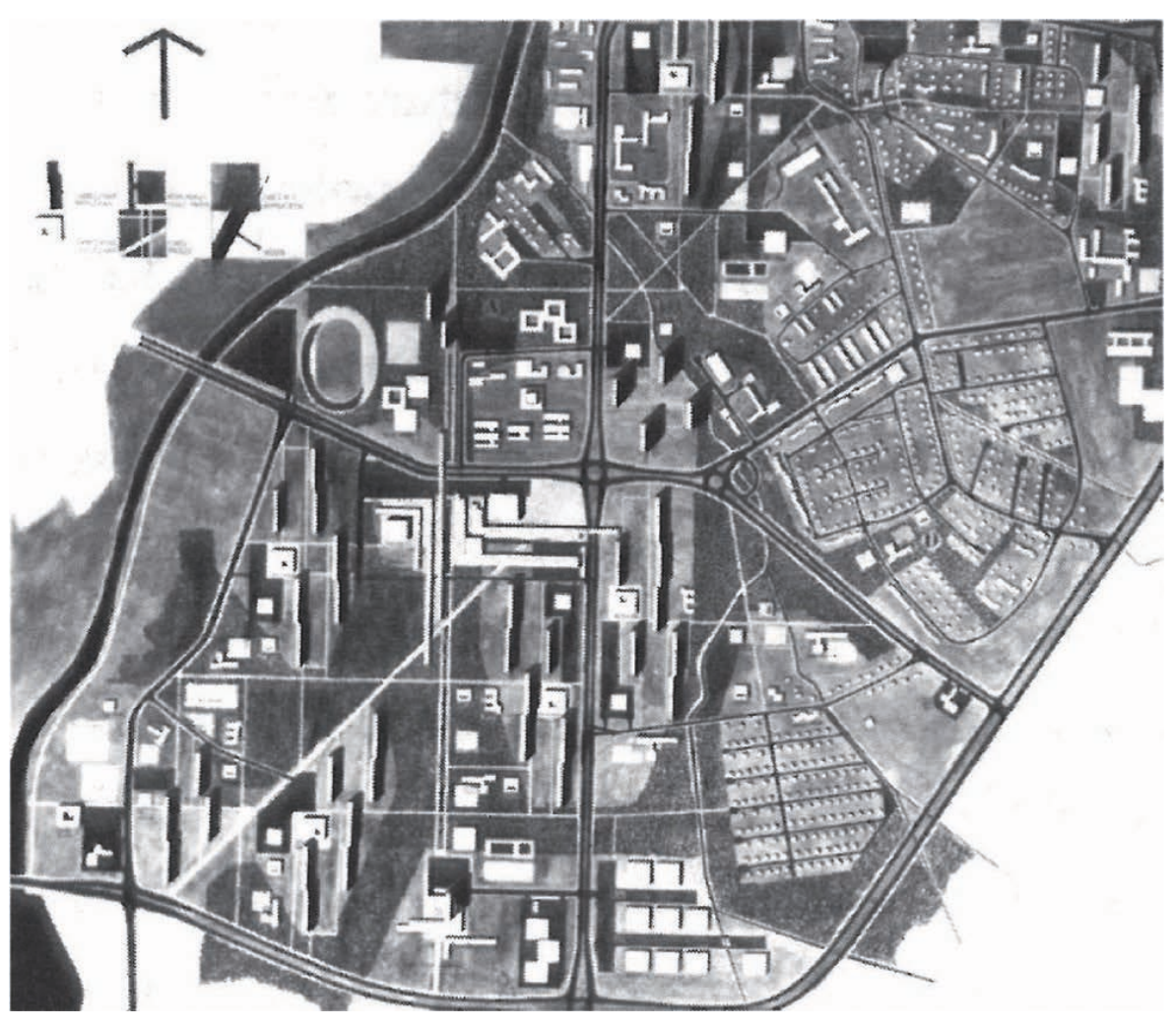

the full range of basic services functions were to be included, both in the vicinity of the apartment blocks and in their ground floors (Henning, 2012).

Construction of the estate began in 1973. For financial reasons, the focus was almost exclusively on eleven-storey apartment blocks, the so-called cabinets. The buildings were located equidistantly in a system forming smaller groups of four buildings in a group. Many services have been abandoned, leaving only a few important ones. During construction, the monotony of the system and the negligible aesthetic value of the large objects forming the 'concrete wall' were noticed, thus only a fragment of the plan was implemented. The original design planned the location of the arranged recreational and leisure greenery along the Wistok River. The new city in the socialist version appeared as a boring resized residential buildings by prefabricated large concrete slab housing complexes. The turn of the $20^{\text {th }}$ and $21^{\text {st }}$ centuries brought thermal insulation processes and postmodern accidental colours, which to this day disfigure the buildings of the estate.

\section{New City XXI - areas connected in the $21^{\text {st }}$ century}

In 2006, the process of the administrative expansion of the territory of the city of Rzeszów began. The borders were moved in 2006, 2007, 2008, 2009, 2010, 2017 and 2019. Since 2006, the city has more than doubled its area and the population has increased by around 40,000 residents. Every year, the city submits applications for connecting new areas and even entire villages, but it does so without consulting the neighbouring municipalities, which consistently disagree with such a policy.

The city structures described in earlier chapters (New Town XVI and New Town XX) have a common feature - the basis of their creation were cubature projects; in the first case, the central square and surrounding buildings, in the second, the housing estate project. It seems that the city authorities of the time interpreted the living space by literally translating the needs into the language of technology and thus creating closed urban compositions with detail in the form of specific objects with a precise function and form. 


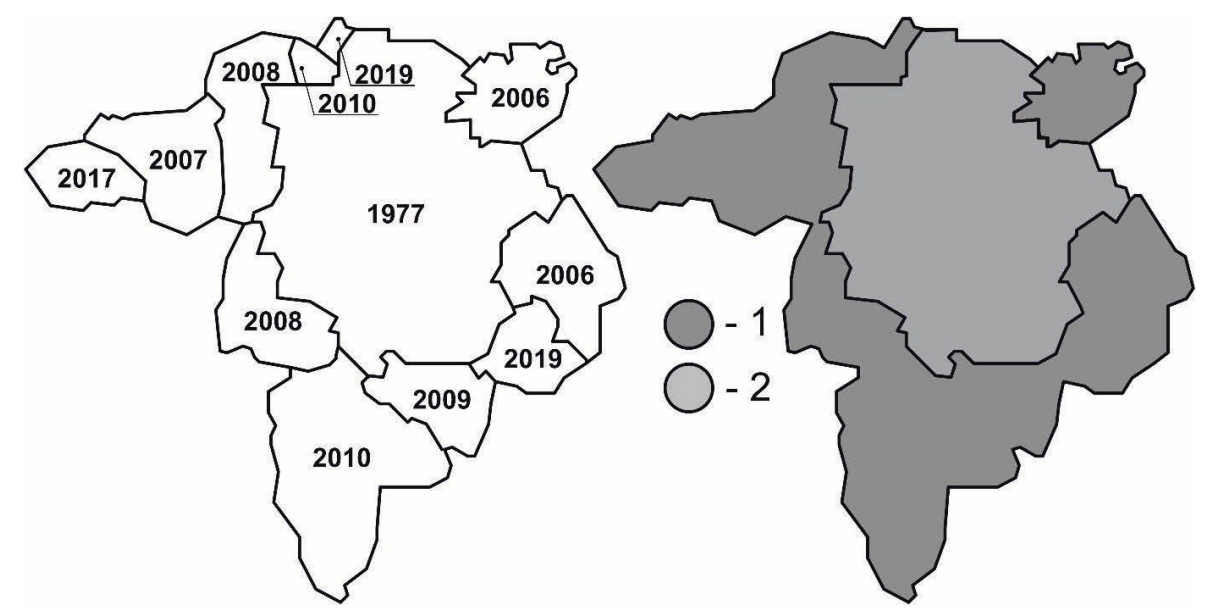

The attached areas significantly differ in structure from the areas within the borders of 1977. For the purposes of the article, they are called the 1977 City. While the granularity of the structure of the 1977 City is coarse-grained diversified and characteristic of the urban tissue - the area of New Town XXI outside the western areas is dominated by small-grain single-family housing. At the same time, there is no development policy for these areas, let alone a cubature project. The municipal authorities of Rzeszów have not adopted a comprehensive Study of Conditions and Directions of Spatial Development (Studium Uwarunkowań i Kierunków Zagospodarowania Przestrzennego) since the beginning of joining, and in the adjacent areas, the 'studies of neighbouring municipalities' adopted for rural areas apply. The exception is small fragments of the area for which changes were made to the study 'for specific investments' (Sikora, 2017).

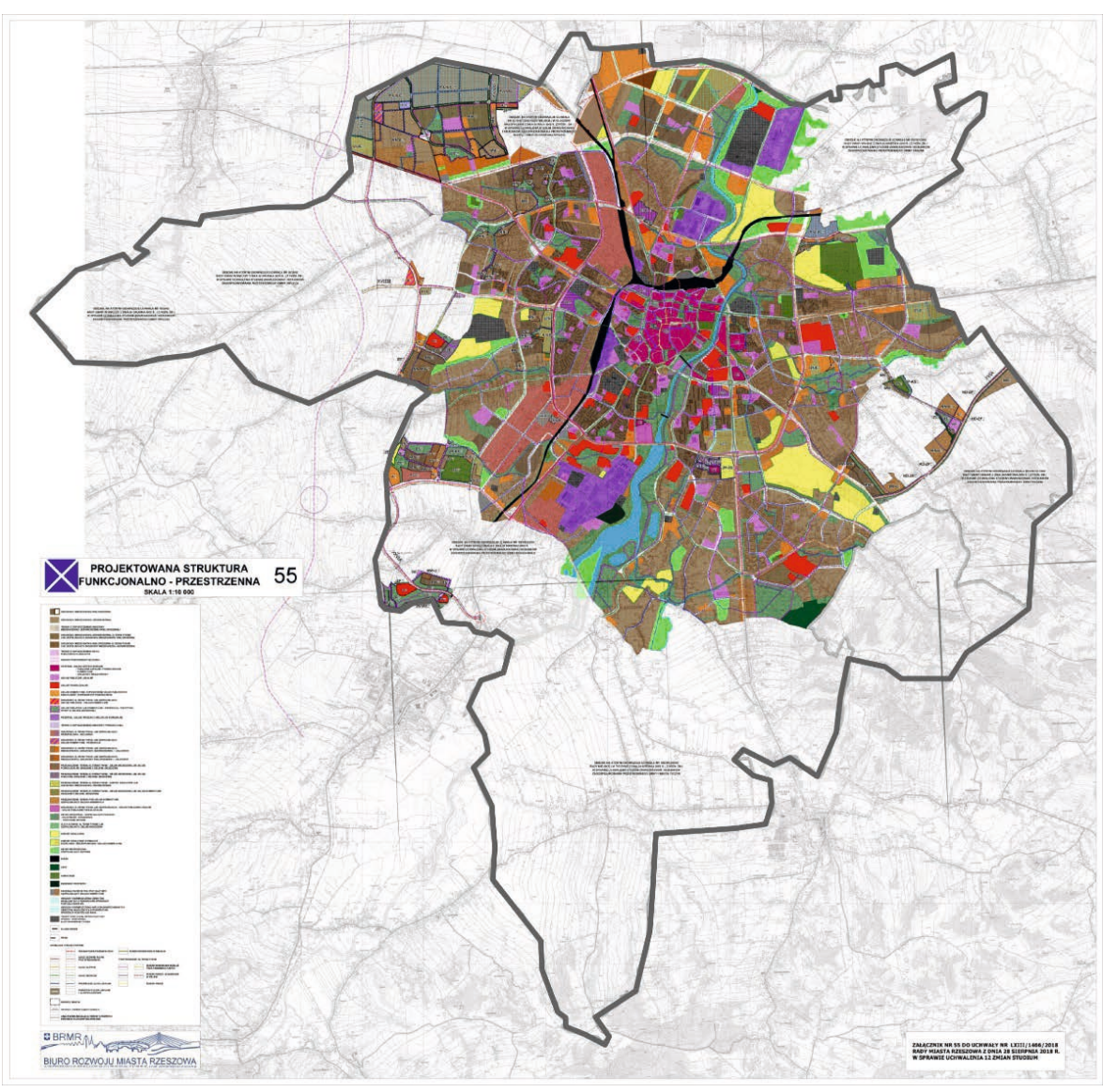

Fig. 3. The changing borders of Rzeszów in 1977-2006-2019 together with detailing the areas of urban fabric within the borders of 1977 and the $21^{\text {st }}$ century 'new town' within the borders from 2006 to 2019. Designation: 1 - city area within the borders of 1977 (Town 1977), 2 - city area within the borders of 2006-2019 (New Town XXI) (own studies)

Fig. 4. Areas within the city limits covered by the findings of the Study of Conditions and Directions of Spatial Development (Studium Uwarunkowań i Kierunków Zagospodarowania Przestrzennego); areas of the non-drawn map are connected areas in which SCDSD are in force, adopted by the municipalities within which these areas were located before joining the city (source: bip.erzeszow.pl, study board 55 designed functional and spatial structure of the city, date of access: 2020/06/01) 


\section{口::: technical

Fig. 5. Connected areas - New Town XXI, structure and granularity. Designations: A - Stocina housing estate, the area connected in 2006, B, C - Przybyszówka housing estate, the area connected in 2008, D - Matysówka housing estate, the area connected in 2019 (own studies, orthophotomap obtained from mapy.geoportal.gov.pl, date of access: 2020/11/11)

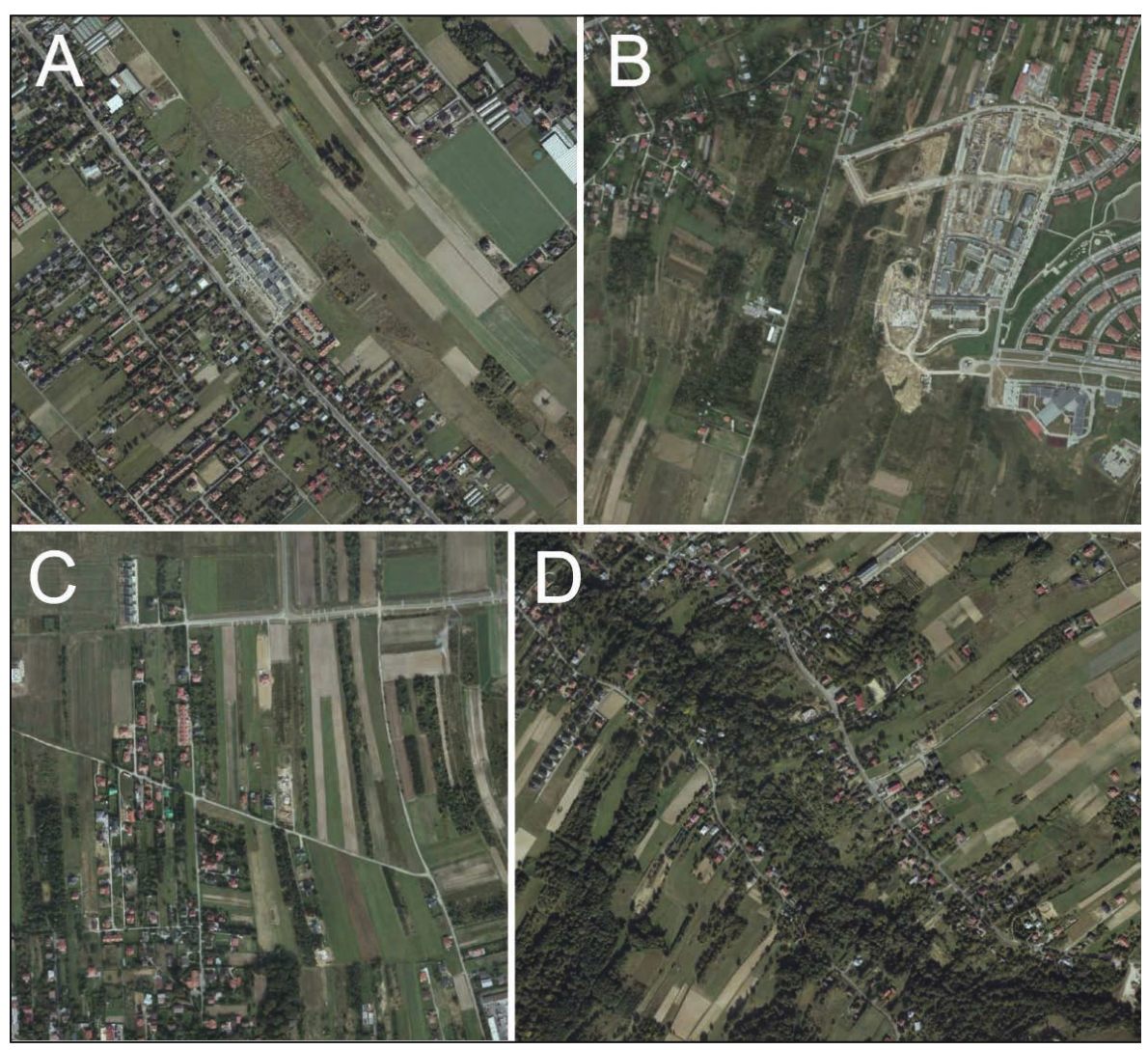

With regard to Local Spatial Development Plans (Miejscowy Plan Zagospodarowania Przestrzennego, they are extremely rarely adopted and the municipality's tasks in shaping spatial policy are based mainly on administrative decisions: decisions on building conditions and land development (decisions on building conditions and decisions on determining the location of public-purpose investments) and decisions on the permission to implement a road investment. This is due to the beliefs of current city authorities that plans often block an investment and location decisions regarding individual investments are a sufficient space-planning tool (Gernard, 2017).

The structure of buildings of New Town XXI is chaotic and bears the signs of uncontrolled suburbanisation. Buildings forming the urban tissue are mainly single-family and farm buildings. In the areas connected first (in 2006 and 2008), a communication system and multi-family housing complexes were built. The most advanced in terms of composition and characterised by the highest level of 'urbanity' (Gyurkovich, 2007) is the fragment of the Przybyszówka housing estate connected in 2008 (Fig. 5B). The Projektant Cooperative continues the construction in the housing estate, which covers a huge housing estate located in the western part of Rzeszów. In the remaining areas, multi-family residential buildings form small groups (Fig. $5 \mathrm{~A}$ ) or occur either individually or not at all (Figs. 5C and 5D).

In terms of composition, orthogonal systems dominate in single-family housing complexes resulting from the way of designing and obtaining permits on the basis of decisions regarding the building conditions. Historically, there were buildings in the chain village in the area. New buildings are often created by marking a road perpendicular to the main street, followed by the serial division into plots. Due to the economic status of the region, there are investments of a few ouses in the area, developers were not interested in buying many plots and mergers in order to create a closed housing complex based on a well thought out, high-quality urban concept. 


\section{Conclusions and summary}

The examples discussed above, based on the city of Rzeszów, are cases of the transformation of structures that are from a given historical period or currently an explication of the phenomenon of building a new city. On the basis of literature studies and a query of cartographic materials, the genesis, social structure and tissue changes related to historical events as well as the needs of residents and other users were examined. The results of the analyses are summarised in Table 1, in which important elements of the morphology of the urban system have been identified in addition to a synthetic outline of the most important elements of the functional and spatial structure and the listing of significant elements of the history of the formation of the urban form (Kantarek, 2019). The study omitted divisions into building plots because their forms are not comparable due to the passage of time (New Town XVI) and forced mergers to build a socialist housing estate (New Town XX).

Table 1. List of morphological features of New Towns in various historical periods and today (own studies)

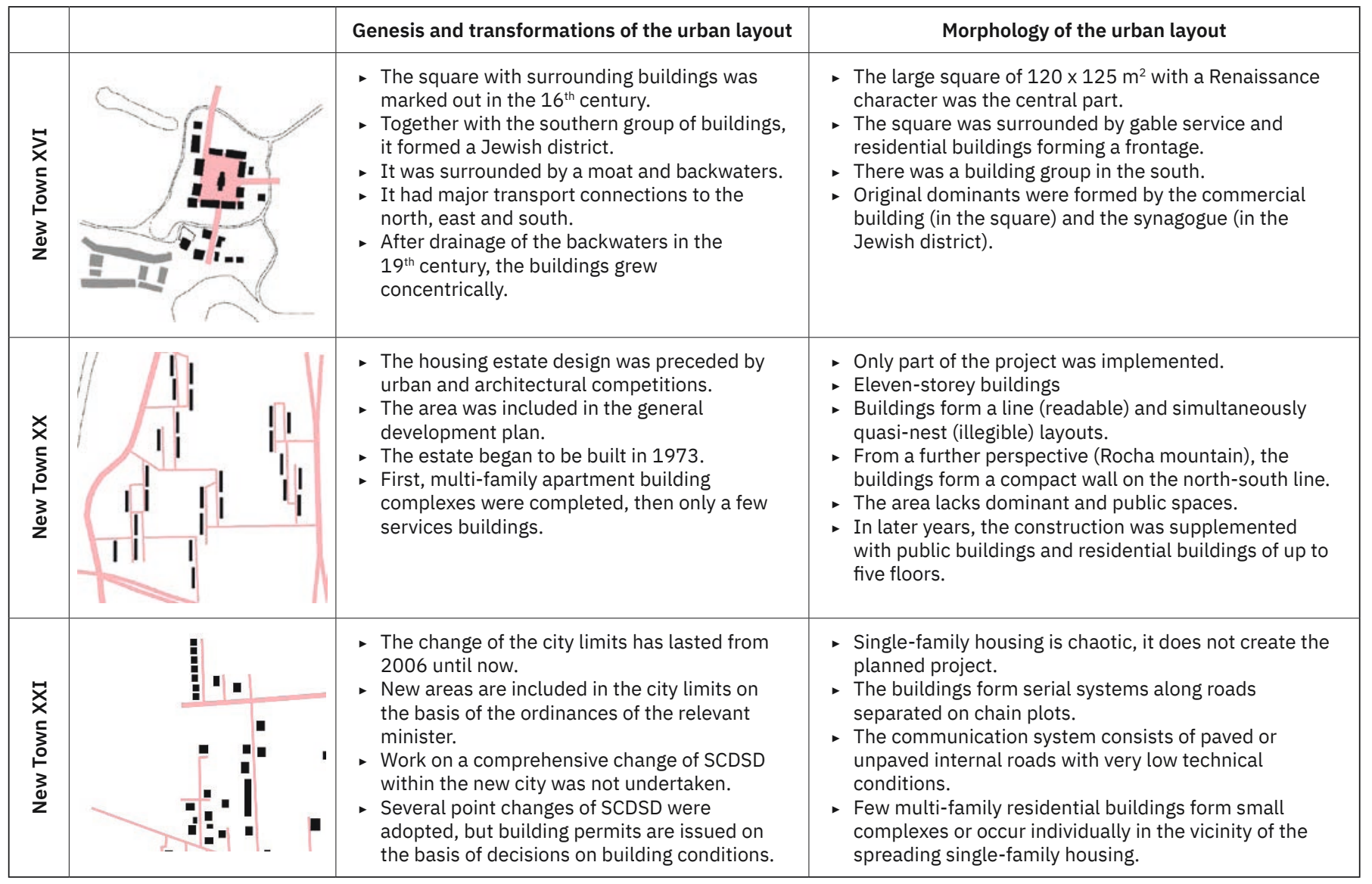

In conclusion, it can be stated that the nature of the buildings significantly differs from the period of the new city's creation. This is associated with both architectural fashion and the beliefs of modern users about the most important social needs. This is clearly seen in the first two examples. In the new Renaissance (mannerist) city, the most important element was a large commercial square surrounded by residential and service frontages (Jastrząb, 2002), while in the new socialist city built according to modernist assumptions, the essence of the urban idea was very tall multi-family residential buildings on large green plots. This location provided good lighting and ventilation for apartments built 'for the minimal existence' (Wojtkun, 2008). 
The modern New Town XXI has a completely different character; it is an area that was connected to the city in 2006-2019. This is due to the poor condition of spatial planning, which has lost its importance in the thirty years following the political transformation in Poland. Good urban planning and spatial order have blurred in the memory of users and municipal authorities, which results in a policy of not carrying out plans. Administrative decisions, and in particular decisions on building conditions, cause an increase in spatial chaos and specific Polish suburbanisation - rows of single-family residential buildings on long plots. Dynamic spatial expansion increases the city's area but does not increase the demand for urban functions such as multi-family housing or commercial and public services. It was also noted that such investments were implemented mainly within the city limits of 1977 near a relatively dense urban fabric of high intensity, and thus have a high population density. Such developer choices are associated with a lack of coordinated planning and implementation activities in relation to the hierarchised road network. The growth of urban tissue requires a new 'communication grid' moved outwards in relation to the existing structure. Such actions are not taken.

In summing up the study, it is worth paying attention to the differences in the quality of the spatial development of 'new cities'. In the modern approach, there is no desire to develop space taking into account the needs of residents and their comfort in understanding the science of urban planning. Perhaps the city is unnecessary (Smagacz-Poziemska, 2015). Perhaps modern technologies and communication possibilities, both in terms of transport and the exchange of thoughts, words and images (Castells, 2008), are enough for city dwellers who no longer need public space (meeting space) and orderly development in a sustainable environment, i.e. aesthetic space. Maybe for the average inhabitant, the need for space comes down to the nearest surroundings - a house, garden or car interior. These questions require research and in-depth reflection, which is significantly beyond the scope of this study. 


\section{References}

Andrzejewska, E., Bazan-Krzywoszańska, A., Skiba, M., Stępkowska, E., (2018). Analiza powiązań strukturalnych dzielnicy Nowe Miasto w Zielonej Górze. Quarterly of Environmental Engineering and Design, 169(49), 49-61. https://doi.org/10.5604/01.3001.0012.2173

Areas within the city limits covered by the findings of the Study of Conditions and Directions of Spatial Development. (2020). Retrieved from bip.erzeszow.pl (date of access: 2020/06/01).

Castells, M. (2008). Spoteczeństwo sieci. Warszawa: Wydawnictwo Naukowe PWN.

Gernard, A. (2017). Tadeusz Ferenc do deweloperów: Do wyborów zostat rok. Budujcie jak najwięcej. Retrieved from https://rzeszow.wyborcza.pl/ (date of access: 2019/11/14).

Gosztyła, M., Mikrut, A. (2017). Urbanistyka miasta Rzeszowa w aspektach historycznych. Journal of Civil Engineering, Environment and Architecture, XXXIV(64), 79-90. https://doi.org/10.7862/rb.2017.155

Gyurkovich, J. (2007). Urban Urbanity. Czasopismo Techniczne, 2-A, 105-118.

Henning, W. (2012). Rzeszowski alfabet miejsc często już zapomnianych i osób z nimi związanych. Rzeszów.

Jastrząb, T. (2002). Place i rynki jako zagadnienie urbanistyczne. Poznań: Wydawnictwo Politechniki Poznańskiej.

Kantarek, A.A. (2019). Tkanka urbanistyczna. Wybrane zagadnienia. Kraków: Wydawnictwo Politechniki Krakowskiej.

Kiryk, F. (Ed.). (1994). Dzieje Rzeszowa. Tom I: Rzeszów od najdawniejszych czasów do I rozbioru. Rzeszów: Krajowa Agencja Wydawnicza.

Kiryk, F. (Ed.) (1998). Dzieje Rzeszowa. Tom II: Rzeszów w czasach zaborów i niewoli (1772-1918). Rzeszów: Krajowa Agencja Wydawnicza.

Klaassen, L.H. (1981). Theoretical issues in urban dynamics. In L.H. Klaassen, W.T.M. Molle, J.H.P. Paelinck (Eds.), Dynamics of urban development (pp. 8-30). Aldershot: Gower.

Kotula, F. (1985). Tamten Rzeszów. Rzeszów: Krajowa Agencja Wydawnicza.

Le Corbusier. (2017). Karta Ateńska. Warszawa: Fundacja Centrum Architektury.

Malisz, B. (1981). Zarys teorii kształtowania układów osadniczych. Warszawa: Wydawnictwo Arkady.

Moskal, T. (2015). Geneza i ewolucja struktury przestrzennej osiedla mieszkaniowego Nowe Miasto w Rzeszowie. Housing Environment, 14, 158-167.

Orthophotomap. (2020). Retrieved from mapy.geoportal.gov.pl (date of access: 2020/11/11).

Pęckowski, J. (1913). Dzieje miasta Rzeszowa do końca XVIII wieku. Rzeszów.

Sikora, A. (2008). Nowe przestrzenie publiczne jako element integracji funkcji śródmiejskich Rzeszowa. Czasopismo Techniczne, 4-A, 143-147.

Sikora, A., Hrehorowicz-Gaber, H. (2017). Przeksztatcenia nowych terytoriów miejskich na przykładzie Rzeszowa. Journal of Civil Engineering, Environment and Architecture, XXXIV(64), 315-322. https://doi.org/10.7862/rb.2017.215

Smagacz-Poziemska, M. (2015). Czy Miasto jest niepotrzebne? (Nowe) przestrzenie życiowe mtodych mieszkańców miasta. Warszawa: Wydawnictwo Naukowe Scholar.

Wojtkun, G. (2008). Wielorodzinne budownictwo mieszkaniowe. Wizje a rzeczywistość. Szczecin: Politechnika Szczecińska.

Wzorek, Z. (1953). Rzeszów - studia do planu śródmieścia. Miasto, 9(35), 21-25. 